\title{
Liquid Biphasic System: A Recent Bioseparation Technology
}

\author{
Kuan Shiong Khoo ${ }^{1}$, Hui Yi Leong ${ }^{2}$, Kit Wayne Chew ${ }^{3}{ }^{1}$, Jun-Wei Lim ${ }^{4}{ }^{(}$, Tau Chuan Ling ${ }^{5}$, \\ Pau Loke Show ${ }^{1, *}$ and Hong-Wei Yen ${ }^{6,7, *}$
}

1 Department of Chemical and Environmental Engineering, Faculty of Science and Engineering, University of Nottingham Malaysia, Jalan Broga, Semenyih 43500, Malaysia; kuanshiong.khoo@hotmail.com

2 College of Chemical and Biological Engineering, Zhejiang University, Hangzhou 310027, China; leong.hy@zju.edu.cn or isabellelhy@gmail.com

3 School of Mathematical Sciences, Faculty of Science and Engineering, University of Nottingham Malaysia, Jalan Broga, Semenyih 43500, Malaysia; KitWayne.Chew@nottingham.edu.my

4 Department of Fundamental and Applied Sciences, Centre for Biofuel and Biochemical Research, Institute of Self-Sustainable Building, Universiti Teknologi PETRONAS, 32610 Seri Iskandar, Malaysia; junwei.lim@utp.edu.my

5 Institute of Biological Sciences, Faculty of Science, University of Malaya, Kuala Lumpur 50603, Malaysia; tcling@um.edu.my

6 Taipei Economic and Cultural Office, Prague, Czech Republic, Evropská 33C, 16000 Praha 6, Czechia

7 Department of Chemical and Material Engineering, Tunghai University, Taiwan 407

* Correspondence: PauLoke.Show@nottingham.edu.my (P.L.S.); hwyen@most.gov.tw (H.-W.Y.)

Received: 16 December 2019; Accepted: 17 January 2020; Published: 23 January 2020

\begin{abstract}
A well-known bioseparation technique namely liquid biphasic system (LBS) has attracted many researchers' interest for being an alternative bioseparation technology for various kinds of biomolecules. The present review begins with an in-depth discussion on the fundamental principle of LBS and this is followed by the discussion on further development of various phase-forming components in LBS. Additionally, the implementation of various advance technologies to the LBS that is beneficial towards the efficiency of LBS for the extraction, separation, and purification of biomolecules was discussed. The key parameters affecting the LBS were presented and evaluated. Moreover, future prospect and challenges were highlighted to be a useful guide for future development of LBS. The efforts presented in this review will provide an insight for future researches in liquid-liquid separation techniques.
\end{abstract}

Keywords: liquid biphasic system; aqueous two-phase system; aqueous biphasic system; purification; separation; recovery; biomolecules

\section{Introduction}

The most trending research in the downstream biotechnology industries focuses on the production of various bio-based products from renewable sources. Examples of these sources are microalgae, fruit, lignocellulose biomass, secondary product, and crop waste. Separation and purification techniques for the recovery of biomolecules (e.g., proteins, carotenoids, and lipids) requires a precise operating condition to ensure high value end-products can be obtained [1,2]. Established extraction techniques such as membrane separation, chromatography-based method, ultrafiltration, and precipitation usually involve multiple step operations, complex pathways, time consuming operations, high energy inputs, and high cost for the recovery and extraction processes [3-5]. With that said, researchers are putting tremendous efforts in developing a new separation and purification techniques which can be performed in a one-step extraction process within a shorter period of time. On the other hand, the extraction 
solvents in a process that can be reused and recycled will lower the overall processing cost [6]. As for food and pharmaceutical applications, this requires an alternative non-toxic and environmentally friendly extraction solvents [7].

A well-established bioseparation technology namely liquid biphasic system (LBS) has attracted numerous researchers' attentions in the separation and purification of biomolecules [8]. It is also known as liquid-liquid extraction technology in the downstream processing. The concerns associated from the conventional extraction method has been overcome by using liquid biphasic separation techniques. The liquid biphasic extraction technology is comprised of two liquids which is separated by an interfacial layer when the mixture of two incompatible liquids is beyond the critical condition. Generally, the characteristics of the phase-forming components creates a physico-chemical interaction which can easily acclimatize the target biomolecules to be partitioned to either the top or bottom phase depending on the selectivity of the components. Furthermore, various assisted technologies such as bubbling, ultrasound, and electrolysis have been incorporated into the LBS to enhance the effectiveness of biomolecules separation [9-12]. The application of the LBS has been applied for the extraction, separation, and purification of proteins, lipids, and carotenoids from microalgae [2,13].

This review article strives to summarize the cognitive knowledge and previous experimental research dealing with LBS for extraction and purification of various biomolecules. This review begins with the principles and fundamentals of LBS, followed by the various type of biphasic systems were presented. Recent works related with advance technologies such as bubble-, ultrasound, and electricity-assisted LBS were evaluated and assessed. Additional information regards to the quantification (i.e., partition coefficient, selectivity, separation efficiency, and recovery yield) and composition of LBS were tabulated with provided references in Sections 2 and 3. Each section in this review would allow the readers to understand the development of LBS technologies. Moreover, the key parameters affecting the extraction efficiency in LBS, advantages and drawbacks of LBS were comprehensively discussed. In addition, future prospect and challenges associated with LBS were also discussed. This review article has a significant impact on the liquid-liquid extraction and purification for various biotechnological products, which serve as a resourceful tool for researchers dealing with extraction of biomolecules using LBS.

\section{Liquid Biphasic System}

Liquid biphasic system (LBS) or commonly known as aqueous two-phase system (ATPS) has been long introduced for the separation, recovery, and purification of biomolecules, and it is the current research trend adopted in the separation and purification technology. It was started back in 1896 when Martinus Willem Beijerinck accidentally mixed an aqueous starch solution with gelatin and found that an immersible layer was formed between both the aqueous solutions [14,15]. This idea of LBS as an analytical separation technique was sparked by Per-Åke Albertsson in the 1960s who discovered the phenomenon by mixing two different polymers (e.g., polyethylene glycol and dextran) resulting in an aqueous medium containing two separable phases $[14,16,17]$. This application was then extended to several generations of scientists and engineers who have been working in the industrial biotechnology field. Figure 1 shows a schematic diagram of the principles of LBS.

The LBS is well-known for the extraction of different biotechnological materials such as proteins, lipids, and carotenoids $[1,18,19]$. The specialty of LBS compared to traditional organic solvent extraction techniques is the composition of the phase-forming components which contains large amount of water while maintaining a low interfacial layer that separates both phases. It can be either used to separate proteins from cellular debris or to purify targeted proteins from contaminated proteins. Likewise, LBS has the capability of directing the target biomolecules by partitioning them to the top phase for extraction [20]. Conventional polymer-based LBS which possess a low ionic system is generally used for the separation and purification of biomolecules which are sensitive toward ionic condition [16]. Nevertheless, polymer-based LBS was neglected due to lack of compatibility between high ionic strength biomolecules, expensive phase-forming components, and its high viscosity 
system. Further development in LBS using different phase-forming components such as alcohol-, ionic liquids-, deep-eutectic solvent- and surfactant-based was utilized to replace the conventional polymer-based LBS.

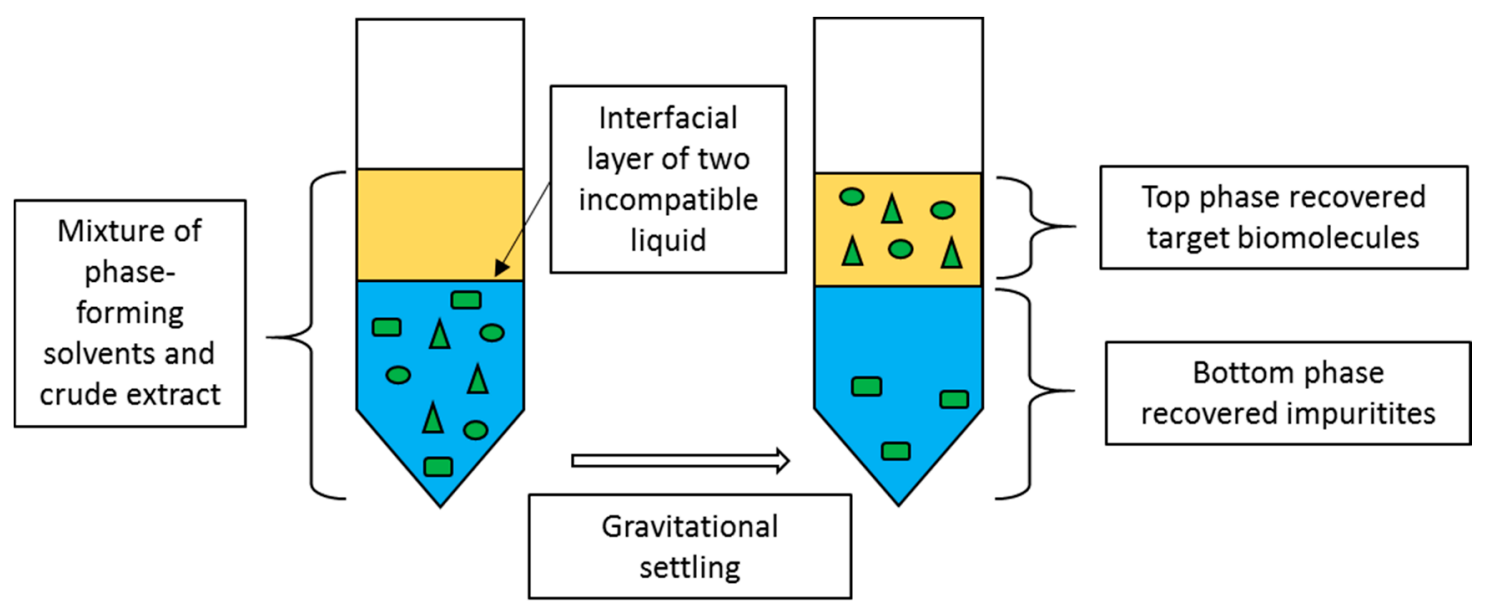

Figure 1. Schematic diagram of the principle in the liquid biphasic system (LBS).

The selective partitioning of the LBS allows the extraction of biomolecules to be operated in a single-step process compared to traditional extraction techniques which require multiple operation steps. LBS possess an environmental-friendly, inexpensive, ease of scaling-up, rapid, and efficient techniques for recovery and purification of biomolecules. During the planning stage, it is crucial to understand the complexity of the physical and chemical interaction reaction throughout the partitioning process in the LBS [21]. The selection of various parameters which are compatible to the system properties are important to achieve an optimal extraction, recovery, and purification condition. It is also important to evaluate the interactions during the selection of various parameters (e.g., salt precipitation, crystallization, and absence of biphasic system) as it may affect the findings. Lastly, is to assess the effect of each process parameters on the product recovery and purity [21].

Fundamental principles for the formation of LBS requires a phase diagram or also called the binodal curve where these provide a set of information regarding the two-phase formation and their required concentration in the top and bottom phases [22]. A detailed study has been evaluated previously by Iqbal et al., (2016) on the tie line length (TLL) and slope tie line (STL) for the construction of phase diagrams [23]. Binodal curves can be constructed using three methods namely, turbidometric titration, cloud point, and node determination method for predetermined phase diagram [22,24,25]. Moreover, the partition coefficient (K) LBS is to evaluate the equilibrium relationship between the top and bottom phase in the LBS. However, there is still lack of studies reporting on the theory and chemistry of these phase forming mixtures in the LBS which is a gap to-be-filled. Apart from that, factors that affect the partition coefficient can be manipulated using electrical, hydrophobicity-phase forming components, bio-specific affinity, molecular size, and surface area to understand the physico-chemical properties of the partitioning mechanism in the LBS.

\subsection{Polymer-Based LBS}

The conventional polymer-based LBS is typically made up of two polymers (e.g., polyethylene glycol (PEG) and dextran) and PEG-salt combinations (e.g., phosphate-, sulphate-, and citrate-based) as the phase-forming components. The purpose of using polymer-based LBS is that the chemical composition of a non-ionic characteristics toward an ionic environment is compatible towards biomolecules having low ionic strength [16]. Aside from that, the phase forming component from polymer-based has the ability to be recycled and reused for subsequent extraction process and this reduces the cost of polymers phase-forming component [26]. Polymer-based LBS are commonly used 
for protein extraction due to its poor hydrophilic and hydrophobic interaction in polymer/salt-based LBS. However, it is important to maintain concentration of salt solution as high salt concentration may denature and damage the fragile protein in the system.

In most work, conventional polymer-based LBS has been replaced by using thermo-separating polymers as the phase-forming component to overwhelm the limitation of polymer-based LBS such as high viscosity and difficulties in recycling process $[27,28]$. Thermo-separating polymers are random, di-block, and tri-block co-polymers of ethylene oxide (EO) and propylene oxide (PO) [29]. Thermo-separating polymers have a low cloud point temperature $\left(\leq 47^{\circ} \mathrm{C}\right)$ which is suitable to achieve temperature-induced phase separation where a target protein can be recovered from the polymer [30]. Generally, a back-extraction process such as ultrafiltration, diafiltration, and crystallization is needed to separate the target protein from the polymer. However, an in-depth understanding on the mechanism by the polymer phase-forming component for the recovery of biomolecules is still poorly understood. This shows a gap for future researchers to further explore the fundamental principles of this LBS extraction technique.

Several studies have been conducted involving cyclodextrin glycosyltransferase (CGTase) from Bacillus cereus. $\mathrm{Ng}$ et al., (2012) reported that the TLL of $41.2 \%(w / w)$, volume ratio $\left(\mathrm{V}_{\mathrm{R}}\right)$ of 1.25 , $\mathrm{pH} 7$, and crude loading $(w / w)$ of $20 \%$ were the optimal conditions to recover cyclodextrins using polymer-based LBS with ethylene oxide-propylene oxide (EOPO) 3900 and two phosphate salts [31]. This experiment showed that the highest CGTase was purified up to 13.1 -fold with a yield of $87 \%$ recovered in the EOPO-rich top phase. However, this experiment did not discuss the time period in cyclodextrins recovery. Another research carried out by Lin et al. [32] with modified method using flotation technique and the combination of PEG 8000 and potassium phosphate salt. The optimum conditions in cyclodextrins (CDs) recovery was optimized at 18\% (w/w) PEG 8000 and $7.0 \%(w / w)$ potassium phosphate with TLL of $27.2 \%(w / w), \mathrm{V}_{\mathrm{R}}$ of $3.0, \mathrm{pH} 7$, and crude loading $(w / w)$ of $20 \%$. The experiment showed that the recovery of CDs was affected by alternating each of the parameters such as $\mathrm{TLL}, \mathrm{V}_{\mathrm{R}}$, and $\mathrm{pH}$ where the purification factor $\left(\mathrm{P}_{\mathrm{FT}}\right)$, which corresponded to the highest CGTase purity up to 21.8 with a yield of $97.1 \%$, was recovered in the PEG-rich top phase within a short period [32].

A similar approach utilizing polymer-based LBS was employed for the recovery of lignin peroxidase from Amauroderma rugosum (Blume and T. Nees) [33]. However, this experiment used a lower molecular weight (PEG 600) for a high purification of lignin peroxidase. Generally, this approach showed that a higher molecular weight polymer reduces the purification factor of lignin peroxidase due to the interaction of PEG and hydrophobic enzyme. An optimal condition in lignin peroxidase recovery was optimized at 15\% (w/w) PEG 600 and 16\% (w/w) dipotassium phosphate with highest purification factor of $1.33 \pm 0.62$ and recovery yield of $72.18 \pm 8.50 \%$.

\subsection{Organic Solvent-Based LBS}

Organic solvent-based LBS consists of various water-miscible alcohols (e.g., methanol, ethanol, 1-propanol, and 2-propanol) and inorganic salts. This form of LBS has been utilized to overcome the limitation of polymer-based LBS to improve the recovery of biomolecules from the phase-forming component [7]. The use of alcohol as the phase-forming components can easily recover the biomolecules by evaporating the alcohol from the top phase. A recent study also showed a greener approach using food grade alcohol such as ethanol and 2-propanol compared to the conventional polymer-based LBS for the extraction and recovery of carotenoids from microalgae [7]. Additionally, the phase-forming component can reduce the cost of the process by recycling and reusing the alcohol using rotary evaporator for the next extraction process. Despite its advantages, the drawbacks of using alcohol, especially methanol, as the phase-forming component is the toxicity and hazardous effects towards the environment.

Ooi et al. (2009) reported a study on purification of lipase from Burkholderia pseudomallei using alcohol/salt-based LBS [19]. The best lipase recovery was achieved in LBS composed of $16 \%(w / w)$ of 2-propanol, $16 \%(w / w)$ of potassium phosphate and $4.5 \%(w / v)$ sodium chloride with a purification 
factor of 13.5 along with the yield of $99 \%$. The presence of alcohol component in LBS also did not inhibit the enzymatic activity of purified lipase. The effect of $\mathrm{NaCl}$ on lipase partitioning was found to generate an electrical potential difference in the LBS [34]. An increase in the salt concentration could generate an electrostatic potential that strongly expelled the negatively charge biomolecules toward the water-miscible alcohol in top phase, thus resulting in a high recovery yield.

Lin et al., (2013) conducted a study using alcohol/salt-based LBS to recover the intracellular human recombinant interferon- $\alpha 2 b$ (IFN- $\alpha 2 b$ ) from Escherichia coli [34]. A different variety of combinations between alcohol-based top phase (ethanol, 1-propanol and 2-propanol) and salt phase (ammonium sulfate, dipotassium hydrogen phosphate, and monosodium citrate) were conducted. LBS composed of $18 \%(w / w)$ of propanol and $22 \%(w / w)$ ammonium sulfate in $1 \%(w / w)$ sodium chloride was reported to be the optimal conditions for the purification of IFN- $\alpha 2 b$ achieving a purification factor of 16.2 with the yield of $74.6 \%$. Ammonium sulfate salt was selected due to its high level of $\mathrm{pH}$ in the system which provided a high purification factor of IFN recovery. As the $\mathrm{pH}$ environment in LBS increased, the contaminant protein and IFN protein were partitioned toward water-miscible alcohol top phase. This is mainly due to the negatively charge protein which tends to partition to the top phase and repels from the salt-rich bottom phase [34].

A recent study conducted on a recyclability test utilizing 1-propanol and ammonium sulfate system for the phlorotannin recovery from Padina australis and Sargassum binderi [35]. The highest recovery of phlorotannin were $76.1 \%$ and $91.67 \%$ with purification factor of 2.49 and 1.59 from Padina australis and Sargassum binderi, respectively. A consistent recovery of phlorotannin was obtained after conducting two cycles of the system. This showed a feasible and eco-friendly approach of utilizing the alcohol-based LBS for biomolecules extraction.

\subsection{Ionic Liquid-Based LBS}

A new trend of research by using ionic liquids (ILs) have been an alternative organic compound and non-volatile green solvent in the downstream processes. Their remarkable properties such as negligible vapor pressure, low melting point and high thermal stability have received numerous attention from researchers [36,37]. ILs are composed with tuneable physico-chemical properties of cationic and anionic ions [38]. The cationic part of ILs usually consists of choline cation, ammonium cation, quaternary ammonium or phosphonium, and guanidium cation. As for the anionic part, it consists of environmentally friendly sources such as carboxylic acid, amino acid and biological buffers. Thus, replacing ILs as the phase-forming component in LBS would be beneficial for the extraction and purification of specific target biomolecules from complex crude extract [39]. Additionally, ILs have also been employed for various applications such as electrolytes (e.g., fuel cells, batteries and sensors), $\mathrm{CO}_{2}$ capture, lubricants, and fuel additives. The cost of reactant for the synthesis of ILs are expensive. Therefore, it is important for ILs to be recycle- and reuse-able to ensure that ILs-based LBS are more feasible and applicable in the bioprocessing industries for the next extraction processes. A review by Ostadjoo et al., (2017) revealed the green and environmentally friendly, 1-ethyl-3-methylimidazolium acetate ([C2mim][OAc]) for its potential features in the field of lignocellulose biomass dissolution and biopolymer processing [40-42]. Yet, there is still insufficient studies related to their toxicity and eco-friendliness on scaling up these ILs, especially imidazole- and pyridinium-based ILs. Here we recommended that these ILs need to be further fabricated by replacing environmentally-friendly anionic part such as carboxylic acid, amino acid and biological buffers in order to minimize their toxicity in various application.

Gutowski et al. (2003) reported that by mixing imidazole-based ILs and a kosmotropic salt (i.e., $\mathrm{K}_{3} \mathrm{PO}_{4}$ ) would lead to the formation of a biphasic system [43]. This research had gained interest investigating the phase separation behavior of IL-based LBS. The study on protein extraction using IL-based LBS in a single step was conducted by Du et al. (2007). The researchers had successfully extracted the protein from human urine into the IL-rich top phase with a distribution of 10 and enrichment factor of 5 [44]. Apart from that, $\mathrm{Ng}$ et al. (2014) investigated the purification of CGTase 
from Bacillus cereus fermentation broth in IL/salt LBS, composing of 35\% (w/w) of (Emim)BF Bnd $_{4}$ $18 \%(w / w)$ of sodium carbonate with the addition of $3 \%(w / w)$ of $\mathrm{NaCl}$ [45]. The optimized operating conditions showed that the IL-based LBS was a promising approach for the purification and recovery of CGTase in a single step operation attaining a high purification factor of 13.86 and yield of $96.23 \%$. $\mathrm{Ng}$ et al. (2014) also reported that it was crucial in the selection of salt such as citrate and carbonate ions as they played an important role in LBS formation and was able to attract water molecules toward them by forming strong intermolecular interaction [45].

Chang et al., (2018) used a series of alkyl bromide imidazole for the extraction of C-phycocyanin (CPC) from Spirulina platensis and found that the longer the alkyl chain, $\mathrm{C}_{8} \mathrm{MIM}-\mathrm{Br}$ enhanced the extraction efficiency of CPC [46]. The results indicated that by using $\mathrm{C}_{8} \mathrm{MIM}-\mathrm{Br} / \mathrm{salt}$ LBS the maximum extraction efficiency, partition coefficient, and separation factor of CPC were 99.0\%, 36.6, and 5.8 respectively. ILs-based LBS demonstrated an efficient and feasible separation technique for the extraction of various biomolecules from complex crude extract. This was supported by a recent study that evaluated the protein partitioning in ILs-based LBS composed of Iolilyte 221 PG and citrate salts was found to be feasible but complex depending on various factors such as concentration of phase-forming component, $\mathrm{pH}$, temperature, ionic strength, and chemical nature of the target biomolecules [47]. Proteins are negatively charged particles therefore it favours a system $\mathrm{pH}(\geq 6.50)$ higher than the isoelectric point of protein. Moreover, the partition coefficient for tie-line length within $38-76 \%$ were reference points for specific protein (e.g., bovine serum albumin and rubisco) to be partitioned at the top phase.

\subsection{Deep-Eutectic-Solvent-Based LBS}

Deep-eutectic-solvents (DESs) are defined as a subclass from ILs because of their similarity in physical and chemical properties of ILs [48]. The behavior exhibited from DESs are contributed from hydrogen bonding, whereas ILs are dominated by ionic interactions [49]. DESs are more environmentally friendly as compared to ILs (e.g., imidazole- and pyridinium-based ILs) which are toxic and non-biodegradable. The synthesis of DESs is by combining hydrogen bond acceptors (e.g., quaternary ammonium and phosphonium salts) and hydrogen bond donors (e.g., alcohols, carboxylic acid, and amide). A major advantage from DESs are their charge delocalization properties which are responsible for the decrease in melting point of mixture relative to the raw material [50]. The bottleneck from using ILs such as high cost and complex synthesis route have been solved by these DESs. By having the similar characteristic as ILs and exhibiting some distinguishing features, including ease of synthesis, low cost, and valuable for industrial application, DESs have gained interest in many fields especially in LBS [51].

Choline chloride $(\mathrm{ChCl})$ is a convention quaternary salt used to synthesize DESs. ChCl-based DESs have the same advantages with ILs besides showing excellent biodegradability and low toxicity [52]. Zeng et al. (2014) had performed the extraction of bovine serum albumin (BSA) using four different kind of DESs, namely, choline chloride $(\mathrm{ChCl})$-urea, tetramethylammonium chloride (TMACl)-urea, tetrapropylammonium bromide (TPMBr)-urea, and ChCl-methylurea [53]. The extraction efficiency of BSA under the optimum LBS conditions composed of $0.7 \mathrm{~g} \mathrm{~mL}^{-1} \mathrm{ChCl}$-urea and $2.0 \mathrm{~mL}$ dipotassium phosphate, $\mathrm{K}_{2} \mathrm{HPO}_{4}$ could reach up to $100.5 \%$ that collectively highlighted the advantages of the DES-based LBS for the extraction of protein. Unfortunately, this work was unable to back-extract the target protein free from the DES-LBS because of the hydrophilicity characteristic of DES in the aqueous solution.

A similar work with different DESs was investigated by Pang et al. (2017) using DES-based LBS which composed of choline chloride-polyethylene glycol (ChCl-PEG or DES) and sodium carbonate were applied for the extraction of specific protein (i.e., BSA and papain) [52]. ChCl-based DES was prepared by mixing two compounds, $0.68 \mathrm{~g} \mathrm{~mL}^{-1} \mathrm{ChCl}$ and $0.1 \mathrm{~g} \mathrm{~mL}^{-1}$ PEG 2000 at the molar ratio of 20:1, stirring up to $100^{\circ} \mathrm{C}$ until a homogenous colorless liquid was formed. The result showed that the DES- $\mathrm{Na}_{\mathrm{S}} \mathrm{CO}_{3}$ LBS under the optimum condition had successfully obtained a high extraction efficiency 
of BSA (95.16\%) and papain (90.95\%). Moreover, the back-extraction of target protein was performed by extracting $1 \mathrm{~mL}$ DES top phase followed by the addition of ammonium sulfate $\left(\mathrm{NH}_{4}\right)_{2} \mathrm{SO}_{4}$ and $0.45 \mathrm{~mL}$ ethanol to form a new LBS. However, it was found that by increasing the concentration in the salt-rich bottom concentration would lower the efficiency of the back extraction.

A modified DES-based LBS using ultrasonic-assisted were employed for the extraction of ursolic acid from Cynomorium songaricum Rupr [54]. This approach was compared to the convention ultrasonic-extraction method. The recovery yield of ursolic acid was comparable. However, the presence of LBS promotes a higher purification of ursolic acid. The recovery yield of ursolic acid was $22.10 \pm 0.44 \mathrm{mg} / \mathrm{g}$ with purification factor of $42.41 \pm 0.84 \%$ as compared to conventional ultrasonic-extraction method where the recovery yield was only $20.9 \pm 0.79 \mathrm{mg} / \mathrm{g}$ with a low purification factor of $20.17 \pm 0.77 \%$.

\subsection{Surfactant/Detergent-Based LBS}

Surfactant-based LBS is the transformation of phase-forming component from conventional polymer-based LBS. The surfactant-based LBS is formed when both cationic and anionic surfactants are separated into two immiscible liquid phases which consist of a high concentration than critical micelle concentration (CMC) and at certain molar ratio of cationic and anionic surfactant composition. This novel approach of surfactant-LBS has gained interest mainly due to the combination phase which exist in many different forms (i.e., spherical micelles, rod-like micelles, or vesicles) by simply alternating different composition and concentration of surfactants [55]. The principle of surfactant-based LBS used the cloud point extraction (CPE) system in which the non-ionic surfactant is heated above the cloud point temperature, causing dehydration of detergent for the phenomenon of phase separation to occur [56]. The surfactant-LBS consists of one surfactant-rich phase and the other is the surfactant-dilute phase. The organic contaminant will partition into the surfactant-rich phase and will then aggregate and concentrate at that phase. The presence of small amount of remediated water in the contaminant will remain in the surfactant-dilute phase. Surfactant-based LBS is commonly used to separate hydrophobic and amphiphilic molecules by solubilization and partitioning of membrane-bound substances.

Surfactant-based LBS composed of $24 \%(w / w)$ Triton X-100 and $20 \%(w / w)$ xylitol was used for the purification of lipase from pumpkin seeds [57]. The results showed that the surfactant-based LBS had the ability to partition the lipase into the top surfactant-rich phase and leave the impurities at the bottom xylitol-rich phase. The proposed optimized method had successfully recovered the enzyme with purification factor of 16.4 and yield of $97 \%$. This study also demonstrated that the recovery phase component could be recycled up to five runs with a high percentage of recovery of $97 \%$. However, it was noted that there was a significant decrease in recovery of the phase component after the fifth cycle in which could be mainly due to the accumulation of impurities present in the phase component.

An example of surfactant-based LBS extraction was conducted by Sankaran et al. (2018) using surfactant and xylitol under the optimum operation condition of $25 \% w / w$ of xylitol concentration, $15 \%$ $(w / w)$ Triton $\mathrm{X}-100,80 \%$ w/w of crude lipase, $4 \mathrm{~mL}$ of top phase, $35 \mathrm{~mL}$ of bottom phase, $\mathrm{pH} 7$, and 15 min of flotation time showed the maximum lipase extraction and efficiency of 3.63 and $86.46 \%$ [58]. In addition, the recyclability of both components in surfactant-LBS extraction makes this an excellent process, as this innovative method was practical and feasible to be applied in the biotechnology industry for extraction of other biomolecules. Table 1 summarizes the extraction of biomolecules using various types of phase-forming component in LBS. 
Table 1. Extraction of biomolecules using various types of phase-forming components in LBS.

\begin{tabular}{|c|c|c|c|c|c|c|c|c|}
\hline Type of LBS & Composition of LBS & Type of Feedstock & Biomolecule & Selectivity & $\begin{array}{c}\text { Partition } \\
\text { Coefficient, } \mathrm{K}\end{array}$ & $\begin{array}{l}\text { Purification } \\
\text { Factor, } \mathrm{P}_{\mathrm{FT}}\end{array}$ & Recovery Yield (\%) & Ref. \\
\hline \multirow[t]{3}{*}{ Polymer/salt-based } & $\begin{array}{l}\text { EOPO } 3900 \text { and two } \\
\text { phosphate salts }\end{array}$ & $\begin{array}{l}\text { Bacillus cereus cyclodextrin } \\
\text { glycosyltransferase }\end{array}$ & $\begin{array}{l}\text { Cyclodextringlycosyltransferase } \\
\text { (CGTase) }\end{array}$ & 3.19 & 17.54 & 5.30 & 87.0 & [31] \\
\hline & $\begin{array}{l}18 \%(w / w) \text { PEG } 8000 \text { and } 7.0 \% \\
(w / w) \text { potassium phosphate salts }\end{array}$ & $\begin{array}{l}\text { Bacillus cereus cyclodextrin } \\
\text { glycosyltransferase }\end{array}$ & $\begin{array}{l}\text { Cyclodextringlycosyltransferase } \\
\text { (CGTase) }\end{array}$ & - & - & 21.8 & 97.1 & [32] \\
\hline & $\begin{array}{l}15 \%(w / w) \text { PEG } 600 \text { and } 16 \%(w / w) \\
\text { dipotassium phosphate }\end{array}$ & Amauroderma rugosum & Lignin peroxidase & - & - & $1.33 \pm 0.62$ & $2.18 \pm 8.50$ & [33] \\
\hline \multirow[t]{4}{*}{ Alcohol/salt-based } & $\begin{array}{c}\text { 18\% (w/w) 2-propanol and 22\% } \\
(w / w) \text { ammonium sulfate, } \\
\left(\mathrm{NH}_{4}\right)_{2} \mathrm{SO}_{4}\end{array}$ & Escherichia coli & Interferon (IFN)/ Glycoproteins & - & 0.82 & 16.24 & 74.64 & [34] \\
\hline & $\begin{array}{l}\text { 16\% (w/w) 2-propanol and } 16 \% \\
(w / w) \text { potassium phosphate }\end{array}$ & Burkholderia pseudomallei & Lipase & 287.5 & - & 13.5 & 99.3 & [19] \\
\hline & $\begin{array}{l}\text { 33.5\% }(w / w) \text { of 2-propanol and } 10 \% \\
(w / w) \text { ammonium sulfate }\end{array}$ & Padina australis & Phlorotannin & - & - & 2.49 & 76.1 & [35] \\
\hline & $\begin{array}{c}25 \%(w / w) \text { of 2-propanol and } 12.5 \% \\
(w / w) \text { ammonium sulfate }\end{array}$ & Sargassum binderi & Phlorotannin & - & - & 1.59 & 91.67 & [35] \\
\hline \multirow[t]{2}{*}{ Ionic-liquid based } & $\begin{array}{l}35 \%(w / w) \text { of }(\mathrm{Emim}) \mathrm{BF}_{4} \text { and } 18 \% \\
(w / w) \text { of sodium carbonate } \mathrm{Na}_{2} \mathrm{CO}_{3}\end{array}$ & Fermentation broth & $\begin{array}{l}\text { Bacillus cereus cyclodextrin } \\
\text { glycosyltransferase (CGTase) }\end{array}$ & 9.66 & - & 51.0 & 96.00 & {$[45]$} \\
\hline & $\begin{array}{l}\mathrm{C}_{8} \mathrm{MIM}-\mathrm{Br} \text { and tri-potassium } \\
\text { phosphate }\end{array}$ & Spirulina platensis & C-phycocyanin (CPC) & 5.8 & 36.6 & - & 99.00 & {$[46]$} \\
\hline \multirow[t]{3}{*}{$\begin{array}{l}\text { Deep-eutectic } \\
\text { solvent based }\end{array}$} & $\begin{array}{l}0.7 \mathrm{~g} \mathrm{~mL}^{-1} \mathrm{ChCl} \text {-urea and } 2.0 \mathrm{~mL} \\
\text { dipotassium phosphate, } \mathrm{K}_{2} \mathrm{HPO}_{4}\end{array}$ & Protein & Bovine serum albumin (BSA) & - & - & - & $\begin{array}{l}99.699 .7 \text { and } \\
100.0 \text { BSA }\end{array}$ & {$[53]$} \\
\hline & $\begin{array}{l}\text { Choline chloride and PEG 2000, } \\
\text { molar ratio of 20:1 }\end{array}$ & Protein & $\begin{array}{l}\text { Bovine serum albumin and } \\
\text { papain }\end{array}$ & - & - & - & $\begin{array}{l}\text { Bovine serum } \\
\text { albumin }(95.16), \\
\text { papain }(90.95)\end{array}$ & {$[52]$} \\
\hline & $\begin{array}{c}36 \%(w / w) \text { ChCl-glucose and } 25 \% \\
(w / w) \text { dipotassium phosphate, } \\
\mathrm{K}_{2} \mathrm{HPO}_{4}\end{array}$ & Ursolic acid & Cynomorium songaricum Rupr. & - & - & $42.41 \pm 0.84$ & $22.10 \pm 0.44 \mathrm{mg} / \mathrm{g}$ & {$[54]$} \\
\hline \multirow[t]{2}{*}{$\begin{array}{l}\text { Surfactant/detergent } \\
\text { based }\end{array}$} & $\begin{array}{l}24 \%(w / w) \text { Triton } X-100 \text { and } 20 \% \\
(w / w) \text { xylitol }\end{array}$ & Cucurbita moschata & Lipase & - & - & 16.4 & 97.0 & [57] \\
\hline & $\begin{array}{c}25 \%(w / w) \text { of xylitol concentration, } \\
15 \%(w / w) \text { Triton X-100 }\end{array}$ & Burkholderia cepacia & Lipase & 2.62 & - & 2.56 & 86.46 & [58] \\
\hline
\end{tabular}




\section{Advance Technologies Integrated with LBS}

\subsection{Bubble-Assisted LBS}

Bubble-assisted LBS or known as liquid biphasic flotation (LBF) is the combination of LBS and solvent sublation (SS), in which the biphasic medium composed of organic solvent and aqueous salt solution is aerated by air bubbles (e.g., nitrogen and oxygen) in promoting the adsorption of target biomolecules during the separation process [8] (refer to Figure 2a). SS is an adsorptive bubble separation technique introduced by Sebba who suggested that the use of an immiscible thin organic solvent layer overlaid on top of the liquid bulk as a modification of ion flotation [59]. LBF has accommodated the ease for extraction of high value biomolecules such as protein, lipase, astaxanthin, and betacyanin $[8,10,60,61]$. The theory of LBF system is the phenomenon of surface-active biomolecules having a sorption mechanism between the air bubbles surfaces. The bubbles then arise and dissolve in an organic solvent phase on top of the aqueous solution in the system [11]. With the presence of bubble-assistance in LBS, this could intensively strengthen the adsorption mechanism produced by the bubble transportation; thus, this system is feasible for separation and extraction of biomolecules. Figure 2a illustrates the set-up of bubble-assisted LBS.

A pilot-scale LBF consisting of $0.9 \mathrm{~L}$ of $50 \%(w / w)$ of 1-propanol and $1.5 \mathrm{~L}$ of $250 \mathrm{~g} / \mathrm{L}$ ammonium sulfate salt, $\left(\mathrm{NH}_{4}\right)_{2} \mathrm{SO}_{4}$ had been developed for direct recovery of lipase derived from Burkholderia cepacian [62]. The purpose of this study was to conduct a comparison between the recovery of lipase on pilot-scale and small-scale LBF processes. Preshna et al., (2016) had reported that the pilot-scale alcohol/salt LBF system acquired a purification factor of 12.2 , efficiency of $88 \%$, and a recovery yield of $93.27 \%$ which was feasible for purification of lipase to be implemented into the industrial scale processes [62].

Leong et al. (2018) utilized LBF which composed of $10 \mathrm{~mL}$ of $100 \%$ ethanol, $20 \mathrm{~mL}$ of $200 \mathrm{~g} / \mathrm{L}$ $\mathrm{K}_{2} \mathrm{HPO}_{4}$ salt solution, $1 \mathrm{~g}$ FE (peel or flesh of red-purple pitaya), and 15 min flotation time for betacyanins extraction [8]. The results under the optimum conditions of LBF revealed that the betacyanins extractions from $1 \mathrm{~g}$ FE of peel in alcohol-rich top phase was $95.989 \pm 1.708 \%$ with separation efficiency and partition coefficient of $88.361 \pm 1.708 \%$ and $24.168 \pm 2.949 \%$, respectively. The recovery from $1 \mathrm{~g}$ FE of flesh was $95.488 \pm 0.213 \%$ with separation efficiency and partition coefficient of $94.886 \pm 0.060 \%$ and $21.195 \pm 1.030 \%$, respectively [8]. The objective of this work showed that the LBF has a great potential in bioseparation technology as compared with other extraction techniques such as diffusion extraction, ultrafiltration, and reverse osmosis in which only able to recover $70-75 \%$ of betacyanins [63].

Rather than using alcohol-based LBS, a recent study had showed the extraction of $\alpha$-Lactalbumin from whey used a different phase forming component (i.e., PEG 1000 and citrate salts) along with bubble-assisted technologies showed a separation efficiency and purification fold of $87.54 \%$ and 5.33 [64]. The advantages of this study had showed the feasibility of bubble-assisted technology compared to conventional liquid-liquid extraction providing a low processing cost, rapid, and good separation yield. However, a further study is required to fulfil the gaps in the bubble-assisted technology. This is to ensure a better understanding regarding the mass transfer and the development of kinetics model of LBF in the separation of biomolecules. 
(a)
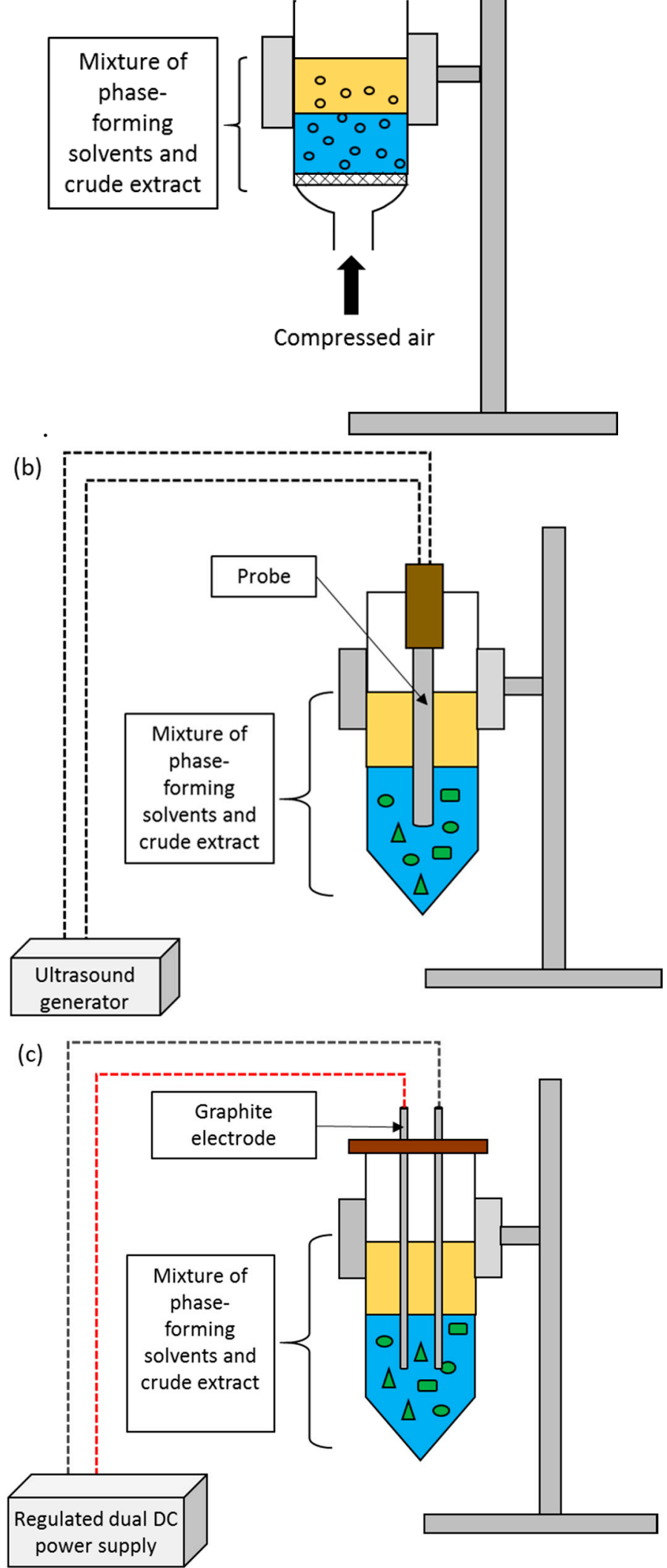

Figure 2. Schematic diagram of (a) bubble-assisted LBS, (b) ultrasound-assisted LBS, and (c) electricity-assisted LBS. 


\subsection{Ultrasound-Assisted LBS}

In the biotechnology processes, cell disruption is considered as the most important process for higher extraction and recovery yield. Ultrasound-assisted LBS is an integrated technique which has been extensively acknowledged by researchers due to its effective properties of cell disruption $[65,66]$. The advantages of ultrasound-assisted LBS includes low operating cost, less energy consumption and short period of time requirement [67]. The fundamental of ultrasound irradiation is the high shear forces produced from cavitation bubbles of ultrasonic waves and mechanical shears which enhanced the cell disruption for effective biomolecules extraction [68]. Figure $2 b$ shows a schematic set-up of ultrasound-assisted LBS.

A recent study conducted by Sankaran et al. (2018) utilized the application of ultrasound-assisted LBS for extraction of protein from Chlorella vulgaris FSP-E microalgae [12]. The authors found that the ultrasound-assisted LBS had the ability to break down the rigid cell wall, followed by the release of protein for extraction. The maximum efficiency and yield of protein were $75 \%$ and $65.4 \%$, respectively [6]. An integrated system of ultrasound and LBF was used to compare the effectiveness recovery of the release protein into the solution for extraction [69]. It was reported that the ultrasound-assisted LBF had better advantages over the ultrasound-assisted LBS, driven by its higher concentration coefficient and a better separation efficiency. This was mainly due to the presence of air bubbles which enabled the adsorption of surface-active proteins from the bottom phase to the top phase. As a result, this led to a higher separation efficiency and recovery yield. This integrated sugaring-out ultrasound-assisted LBF under the optimum conditions composed of $100 \%(w / w)$ acetonitrile, $200 \mathrm{~g} / \mathrm{L}$ glucose concentration, biomass concentration of $0.6 \%$ with $5 \mathrm{~min}$ of $5 \mathrm{~s}$ ON/10 s OFF pulse mode, and at a flow rate of $100 \mathrm{cc} / \mathrm{min}$ had given rise to the protein separation efficiency and recovery yield of $86.38 \%$ and $93.33 \%$, respectively.

Aside from that, ultrasound-assisted extraction has also been widely employed for the cell disruption of lignocellulose biomass from plants [70]. The extraction of phenylethanoid glycosides (e.g., echinacoside and acteoside) from Cistanche deserticola stems using ultrasonic-assisted LBS successfully recovered 27.56 and $30.23 \mathrm{mg} / \mathrm{g}$, respectively [71]. This approach showed that ultrasonic-assisted LBS were efficient, eco-friendly and cheap method for extracting and enriching biomolecules from lignocellulose biomass. However, it is crucial to monitor the process temperature when dealing with ultrasonic irradiation. The high shear forces produced from the cavitation bubbles of sonic wave would generate a high temperature process which will degrade or deform the target biomolecules resulting in an unfavorable low extraction yield. Another supporting research of using the application of ultrasound-assisted LBS was the extraction and separation of antioxidants such as xylooligosaccharides (sugar) and phenolic compound from wheat. In ultrasound-assisted LBS composed of $23.8 \%(w / w)$ ammonium sulfate, $24.3 \%(w / w)$ ethanol, $1.2 \%(w / w)$ biomass loading with ultrasound wave $(30 \mathrm{~Hz}, 500 \mathrm{~W}, 10 \mathrm{~min})$, extraction yielded the highest recovery of sugar and phenols were $16 \mathrm{mg} / \mathrm{g}$ and $2.67 \mathrm{mg} / \mathrm{g}$ dry material [72]. This showed that implementation of ultrasound improved the efficiency of extraction of wheat chaff in LBS yielding 1.3-2 times higher, respectively than those without ultrasound.

\subsection{Electricity-Assisted LBS}

Electricity-assisted LBS (see Figure 2c) is a promising mild cell disintegration extraction technique for recovery of biomolecules. For instance, the electricity treatment such as pulsed electric field (PEF) demonstrates the conceptualization of the initiation of short electrical pulses in the order of magnitude of ms or $\mu$ s subjecting the charge in the cell membrane which is sufficient to perform a rearrangement or disruption of membrane and lead to the pore formation. This process is also known as electroporation. However, an optimum condition is required as PEF is dependent on the intensity of the treatment and cell characteristics in which pore formation is reversible or irreversible [73-75]. PEF treatment also increased the mass transfer energy of the system. By combining both PEF and LBS would be an advantage for an efficient extraction of treated sample. This combination is known as an electropermeabilization where the presence of electric and extractive solvent improves the release of 
intracellular compound from treated sample [76]. Moreover, electricity treatment not only provides higher extraction efficiency of biomolecules but also a greener approach in the biotechnology industries.

Lam et al., (2017) investigated the operating condition required to release selective proteins from the cell wall of Chlamydomonas reinhardtii (cc-124) strain and the cell wall deficient mutant strain (cc-400) using PEF treatment without the presence of LBS [77]. The results showed that after PEF treatment, with operating condition of $5-7.5 \mathrm{kV} / \mathrm{cm}, 1-10$ pulses, and a pulse length of $0.05-0.2 \mathrm{~ms}$ on the cell wall, deficient mutant (cc-400) was on average three times higher than cell wall strain (cc-124) with average protein yield of $31 \pm 6 \%$ protein and $11 \pm 3 \%$ protein. Additional experiments utilizing PEF treatment with low energy input (range between 0.01 and $0.5 \mathrm{kWh} / \mathrm{kg}_{\mathrm{DW}}$ ) were also conducted on cell wall deficient mutant strain (cc-400) with a maximum recovery of $30 \%$ at $0.04 \mathrm{kWh} / \mathrm{kg}_{\mathrm{DW}}$. Furthermore, the results obtained from PEF treatment with low energy input was compared with bead beating which only obtain an average of $34 \pm 4.2 \%$ proteins.

A recent work conducted by Leong et al. (2019) on betacyanins extraction from peel and flesh of red-purple pitaya using the liquid biphasic electric flotation (LBEF) [76] had reported that this new integration process of electricity supplied in LBF system could cause an electropermeabilization of red-purple pitaya membrane structure and improve the betacyanins extraction from red-purple pitaya. An optimum system composed of $100 \%(w / w)$ ethanol, $200 \mathrm{~g} / \mathrm{L}$ of dipotassium hydrogen phosphate $\left(\mathrm{K}_{2} \mathrm{HPO}_{4}\right)$ with $15 \mathrm{~min}$ floatation time (flow rate of 20-30 cc/min), and applied up to $3 \mathrm{~V}$ of voltage using graphitic electrodes showed the highest separation efficiency of betacyanins concentration $(98.383 \pm 0.215 \%$ for peel and $96.576 \pm 0.0083 \%$ for flesh, respectively) [76]. Table 2 summarizes the advance technologies integrated with LBS for the extraction of biomolecules. 
Table 2. Extraction of biomolecules using various types of advance technologies integrated in LBS.

\begin{tabular}{|c|c|c|c|c|c|c|c|c|c|}
\hline Assisted Technology & Composition of LBS & $\begin{array}{l}\text { Type of Assisted } \\
\text { Employed }\end{array}$ & Type of Feedstock & Biomolecule & Time & $\begin{array}{c}\text { Extraction Efficiency, } \\
\text { E (\%) }\end{array}$ & Partition Coefficient, K & Recovery Yield (\%) & Ref \\
\hline \multirow[t]{3}{*}{$\begin{array}{l}\text { Bubble-assisted LBS or } \\
\text { Liquid biphasic } \\
\text { flotation (LBF) } \\
\end{array}$} & $\begin{array}{l}50 \%(w / w) \text { of 1-propanol } \\
\text { and } 250 \mathrm{~g} / \mathrm{L} \text { ammonium } \\
\text { sulfate salt, }\left(\mathrm{NH}_{4}\right)_{2} \mathrm{SO}_{4}\end{array}$ & $\begin{array}{c}\text { Flotation system } \\
\text { (compressed air } 0.5 \text { bar) }\end{array}$ & Burkholderia cepacian & Lipase & $30 \min$ & 88.0 & - & 93.27 & [62] \\
\hline & $\begin{array}{c}100 \% \text { ethanol, } 20 \mathrm{~mL} \text { of } \\
200 \mathrm{~g} / \mathrm{L} \text { dipotassium } \\
\text { phosphate } \mathrm{K}_{2} \mathrm{HPO}_{4}\end{array}$ & $\begin{array}{c}\text { Flotation system } \\
\text { (compressed air } 0.5 \text { bar) }\end{array}$ & Hylocereous polyrhizus & Lipase & $15 \mathrm{~min}$ & $\begin{array}{l}\text { E for peel and flesh were } \\
88.361 \pm 1.708 \% \\
94.886 \pm 0.060 \%\end{array}$ & $\begin{array}{c}\mathrm{K} \text { value of peel and flesh } \\
\text { were } 24.168 \pm 2.949 \\
21.195 \pm 1.030 .\end{array}$ & $\begin{array}{l}\text { Recovery for peel and } \\
\text { flesh were } 95.488 \pm 0.213 \\
94.886 \pm 0.060 .\end{array}$ & [8] \\
\hline & $\begin{array}{l}0.5 \mathrm{~g} / \mathrm{mL} \text { PEG } 1000,35 \mathrm{~mL} \\
\text { of } 0.40 \mathrm{~g} / \mathrm{mL} \text { trisodium } \\
\text { citrate } \mathrm{Na}_{3} \mathrm{C}_{6} \mathrm{H}_{5} \mathrm{O}_{7}\end{array}$ & $\begin{array}{l}\text { Flotation system ( } 30 \\
\mathrm{~mL} / \mathrm{min} \text { flow velocity) }\end{array}$ & Whey & a-lactalbumin & $42 \mathrm{~min}$ & 87.54 & - & - & [64] \\
\hline \multirow[t]{3}{*}{ Ultrasound-assisted LBS } & $\begin{array}{l}100 \%(w / w) \text { acetonitrile } \\
\text { and } 200 \mathrm{~g} / \mathrm{L} \\
\text { glucose solution. }\end{array}$ & $\begin{array}{l}\text { Ultrasound irradiated for } \\
5 \text { min of } 5 \mathrm{~s} \text { ON/10 s OFF } \\
\text { pulse mode and flotation } \\
\text { system }\end{array}$ & Chlorella vulgaris FSP-E & Protein & $5 \min$ & 86.38 & - & 93.33 of protein recovered & [6] \\
\hline & $\begin{array}{l}20 \%(w / w) \text { ethanol and } \\
23.5 \% \text { ammonium sulfate }\end{array}$ & $\begin{array}{l}\text { Ultrasound irradiated } \\
\quad(300 \mathrm{~W}, 37 \mathrm{~min})\end{array}$ & $\begin{array}{l}\text { Cistanche deserticola Y. C. } \\
\text { Ma stems }\end{array}$ & $\begin{array}{l}\text { Phenylethanoid } \\
\text { glycosides }\end{array}$ & $37 \min$ & $\begin{array}{c}\text { Echinacoside and acteoside } \\
\text { were } 5.35 \text { and } 6.22 \mathrm{mg} / \mathrm{g} \\
\text { dry weight }\end{array}$ & - & $\begin{array}{c}\text { Echinacoside and } \\
\text { acteoside were } 27.56 \text { and } \\
30.23 \mathrm{mg} / \mathrm{g} \text { dry wight }\end{array}$ & [71] \\
\hline & $\begin{array}{c}24.3 \%(w / w) \text { ethanol and } \\
23.8 \%(w / w) \\
\text { ammonium sulfate }\end{array}$ & $\begin{array}{l}\text { Ultrasound irradiated ( } 30 \\
\mathrm{~Hz}, 500 \mathrm{~W}, 10 \mathrm{~min})\end{array}$ & Wheat chaff & $\begin{array}{l}\text { Xylooligosaccharides } \\
\text { (sugar) and } \\
\text { phenolic } \\
\text { compound }\end{array}$ & $10 \mathrm{~min}$ & $72.79 \pm 3.98$ & 3.91 & $\begin{array}{l}\text { Recovery of sugar and } \\
\text { phenols were } 16 \mathrm{mg} / \mathrm{g} \\
\text { and } 2.67 \mathrm{mg} / \mathrm{g}\end{array}$ & [72] \\
\hline \multirow[t]{2}{*}{ Electricity-assisted LBS } & Without LBS & $\begin{array}{l}\text { PEF treatment }(5-7.5 \\
\mathrm{kV} / \mathrm{cm}, 1-10 \text { pulses and a } \\
\text { pulse length of } \\
0.05-0.2 \mathrm{~ms})\end{array}$ & $\begin{array}{l}\text { Cell wall C. reinhardtii } \\
\text { strain (cc-124) and cell } \\
\text { wall deficient mutant } \\
\text { strain (cc-400) }\end{array}$ & Protein & $10 \mathrm{~min} /$ pulse & - & - & $\begin{array}{l}\text { Cell wall strain (cc-124) } \\
\text { and cell deficient (cc-400) } \\
\text { with average protein } \\
\text { yield of } 31 \pm 6 \text { protein } \\
\text { and } 11 \pm 3 \text { protein. }\end{array}$ & [77] \\
\hline & $\begin{array}{c}100 \%(w / w) \text { ethanol, } 200 \\
\text { g/L of dipotassium } \\
\text { hydrogen phosphate } \\
\left(\mathrm{K}_{2} \mathrm{HPO}_{4}\right)\end{array}$ & $\begin{array}{l}\text { PEF treatment ( } 3 \mathrm{~V} \text { of } \\
\text { voltage using graphitic } \\
\text { electrodes) and } 15 \mathrm{~min} \\
\text { flotation system }\end{array}$ & $\begin{array}{l}\text { Peel and flesh of } \\
\text { Hylocereus polyrhizus }\end{array}$ & Betacyanins & $15 \min$ & $\begin{array}{c}\text { E for peel and flesh were } \\
98.383 \pm 0.215 \text { and } \\
96.576 \pm 0.083\end{array}$ & $\begin{array}{c}\mathrm{K} \text { for peel and flesh were } \\
100.814 \pm 7.324 \text { and } \\
24.883 \pm 1.052\end{array}$ & $\begin{array}{c}\text { Betacyanins } \\
\text { concentration } \\
(98.383 \pm 0.215 \text { for peel } \\
\text { and } 96.576 \pm 0.0083 \\
\text { for flesh }\end{array}$ & {$[76]$} \\
\hline
\end{tabular}




\section{Key Parameters Affecting LBS}

\subsection{Type and Molecular Weight of Polymer}

In polymer-salt based LBS, the polymer phase component is crucial as it exhibits different degrees of hydrophobicity on target biomolecules partitioning. As the molecular weight of polymer increases, the hydrophobicity also increases due to the long hydrocarbon chain of monomers. This effect causes a reduction in free volume of the polymer-rich top phase, forcing the target biomolecules to be partitioned to the bottom phase. On the other hand, low molecular weight polymer will decrease the purification factor for target biomolecules as it will be partitioned together with contaminant proteins at the polymer-rich top phase [31,32]. Therefore, it is important in selecting an optimum condition for the hydrophobicity of polymers to obtain the maximum recovery of target compounds.

The effect of molecular weight has been discussed with the used of polymers such as PEG and potassium phosphate salt for the recovery of cyclodextringlycosyltransferase (CGTase) from Bacillus cereus [32]. In this work, the different molecular weights of PEG (e.g., PEG 4000, 6000, 8000, 10,000, and 20,000) were used in the LBF system for the CGTase extraction at a constant crude extract to volume ratio of 1.0:3.0. It was found that the maximum purification factor of 7.26 and $97.1 \%$ recovery of CGTase were achieved composed of $18.0 \%(w / w)$ PEG 8000 and $7.0 \%(w / w)$ potassium phosphates LBS. Well, as for the lowest molecular weight, PEG 4000 and highest molecular weight, PEG 20,000 showed a purification factor of 2.25 and 3.23, respectively. This indicated that the low molecular weight polymer (PEG 4000) withdraw contaminant biomolecules to the polymer-rich top phase and the high molecular weight (PEG 20,000) would engender a more viscous phase, resulting in the decrease of free volume of polymer-rich top phase caused by volume exclusion effect. In most cases, it is recommended to start with a low molecular weight, depending on the product compatibility while optimizing the partitioning condition.

In addition, one of the limitations of using PEG and salt as the phase-forming component in LBS is that most of them cannot be recycled for the next process. The non-recyclable phase-forming component makes the overall LBS in downstream processes to be unfavorable as it causes environmental pollution and increases cost operation [78]. To improve the recyclability of phase-forming component in the LBS process, another similar research replaced using thermo-separating polymer (EOPO) as the phase component for the purification and recovery of CGTase [31]. The recovery of EOPO after recyclability was more than $80 \%$ verifying the viability of recyclable characteristics. This simple, rapid and recyclable feature show that the LBS process is a promising and attractive approach for the recovery and purification of target biomolecules.

\subsection{Type and Concentration of Alcohol}

The use of different alcohols (e.g., methanol, ethanol, 1-propanol, and 2-propanol) with different concentrations in the LBS will affect the overall recovery yield of target biomolecules. The exposure of active site from the implementation of organic solvent helps to maintain the enzyme's open conformation and bind the target compounds to the alcohol-rich top phase. A larger amount of alcohol is favorable as it will enhance the target biomolecules buoyancy and stability towards the interface layer.

Santos et al. (2016) conducted an experiment on extraction of caffeine from coffee bean and guaraná seed and reported the possibilities to manipulate the partitioning of caffeine to either the alcohol-rich top phase and salt-rich bottom phase [79]. For caffeine to be partitioned at alcohol-rich top phase, an increase in the concentration of 2-propanol caused the increment in the "caffeine-water" interaction. This effect will promote the biomolecules to be partitioned at the alcohol-rich top phase. Meanwhile, methanol was selected for caffeine to be partitioned at the salt-rich bottom phase. The purpose of selecting methanol was due to its low partition coefficient; therefore, increasing the tendency of caffeine to be partitioned at the salt-rich bottom phase. 
A recent study on recovery of glycyrrhizic acid (GA) and liquiritin (LQ) from Chinese licorice root (Glycyrrhiza uralensis Fisch) reported that $87 \%$ GA and 94\% LQ were successful obtained at alcohol-rich top phase under the optimum condition of $25 \%(w / w)$ ethanol and $30 \%(w / w) \mathrm{K}_{2} \mathrm{HPO}_{4}$ in the LBS [80]. The effect of alcohol concentrations from 14 to $34 \%(w / w)$ and the extraction efficiency and partition coefficient were studied. By increasing the alcohol concentration to $26 \%$ in the system, the extraction efficiency and partition coefficient increased for both GA and LQ biomolecules. However, the extraction efficiency and partition coefficient decreased when the alcohol concentration was increased to $34 \%$. This was due to the large amount of water-soluble alcohol in the alcohol-rich top phase interacting with the water molecules and causing the biomolecules to be partitioned to the salt-rich bottom phase [81]. This term was also referred as "volume exclusion" effect. In general, the selection of alcohol is mainly dependent on the target biomolecules from the complex crude extract. Each target biomolecule has their respective physico-chemical properties and therefore, it is difficult to govern a specific optimum condition for extraction and separation in LBS.

\subsection{Type and Concentration of Salt}

In the LBS, it is critical in selecting the type of salts as the phase-forming component since it can significantly affect the solubility and interaction of the target biomolecules. When the salt is added into a solution, the surface tension of water will increase which then leads to the increase of hydrophobic interaction between protein and water [82]. Few studies had shown that a high saturation level of salt concentration will cause a reduction in solubility of target biomolecules due to the higher salting-out ability of salt [20,36]. Lu et al., (2016) reported that the ability of salt solution and hydrophilic alcohol solution to form a biphasic system was mainly dependent on the Gibbs free energy of salt hydration [83]. The alteration in environmental phase system and behavior of biomolecules partitioning is utilized by the different salt components [84]. Different salts used for the LBS were based on their capability to support hydrophobic interaction between biomolecules [85]. According to the Hofmeister series, the salting-out ability of anions are arranged in the following order: $\mathrm{SO}_{4}{ }^{2-}>\mathrm{HPO}_{4}{ }^{2-}>$ citrate ${ }^{3-}>$ $\mathrm{F}^{-}>\mathrm{Cl}^{-}>\mathrm{Br}^{-}>\mathrm{I}^{-}>\mathrm{NO}^{-3}>\mathrm{ClO}^{4-}$ [25]. However, an optimum condition is required in order to obtain the maximum recovery of target biomolecules. It is also important to select a biodegradable and eco-friendly salt to ensure a more sustainable green approach in utilizing the LBS.

The effect of various salts used has been studied with the use of potassium dihydrogen phosphate $\left(\mathrm{KH}_{2} \mathrm{PO}_{4}\right)$, magnesium sulfate $\left(\mathrm{MgSO}_{4}\right)$ and ammonium sulfate $\left(\left(\mathrm{NH}_{4}\right)_{2} \mathrm{SO}_{4}\right)$ for the extraction of protein from Chlorella sorokiniana microalgae [10]. In this study, the salt concentration of $250 \mathrm{~g} / \mathrm{L}$ were selected for each salt $\left(\mathrm{KH}_{2} \mathrm{PO}_{4}, \mathrm{MgSO}_{4}\right.$, and $\left.\left(\mathrm{NH}_{4}\right)_{2} \mathrm{SO}_{4}\right)$ as an optimum condition in the LBF. It was found that the $\mathrm{KH}_{2} \mathrm{PO}_{4}, \mathrm{MgSO}_{4}$, and $\left(\mathrm{NH}_{4}\right)_{2} \mathrm{SO}_{4}$ exhibited high separation efficiency of $97.85 \%$, $97.74 \%$, and $97.74 \%$, respectively. However, an observation was found using $\mathrm{KH}_{2} \mathrm{PO}_{4}$ solution where a white solid was formed and deposited around the interface at flotation time of $1.5 \mathrm{~min}$, showing its incapability for the separation process. This formation happened when the properties of salt having a low solubility. Thus, an addition process is required to melt the solid salt solution. Another observation found using $\mathrm{MgSO}_{4}$ solution was the absence of interface in the LBF after a flotation time of $4 \mathrm{~min}$. In contrast, it was observed that only $\left(\mathrm{NH}_{4}\right)_{2} \mathrm{SO}_{4}$ solution could clearly render the highest recovery yield and purification values of $56.06 \%$ and $68.99 \%$, respectively. The possible explanation was $\left(\mathrm{NH}_{4}\right)_{2} \mathrm{SO}_{4}$ has a lower molecular weight as compared with $\mathrm{KH}_{2} \mathrm{PO}_{4}$ and $\mathrm{MgSO}_{4}$. As a conclusion, the extraction of protein is more favorable in the alcohol-rich top phase with increasing partitioning coefficient $(\mathrm{K})$ when a low molecular weight salts is used [18,34]. However, the selection of various salts is still dependent on the compatibility of LBS and interaction among biomolecules.

The study of salt concentration was continued by using ammonium sulfate at the concentration range of 100 to $300 \mathrm{~g} / \mathrm{L}$. The effect of increasing salt concentration tends to increase the protein recovery yield. As supported by Phong et al. (2016), it was stated that the salting-out effect would occur at a higher salt concentration, the presence of ions tended to decrease the solubility of protein in the salt-rich bottom phase [9]. A further increase in salt concentration would decrease the protein recovery 
percentage. It was recommended to start with a minimum salt concentration of $20 \%(w / w)$ until the optimum condition was obtained rather introducing a high salt concentration abruptly.

\section{4. $p H$ System}

The partitioning of target biomolecules can be affected by the $\mathrm{pH}$ system in LBS, due to a change in charges and solute properties of solute. The net charge of the target biomolecule becomes negative when the $\mathrm{pH}$ value is greater than the isoelectric point (pI) and positive when $\mathrm{pH}$ value is lower than the pI. If the net charge is equal to zero, both $\mathrm{pH}$ and $\mathrm{pI}$ values are equal [86]. Generally, it is found that in higher $\mathrm{pH}$ system would induce a positive dipole moment causing the partition coefficient to increase; therefore, favor the partitioning of negatively charge target biomolecules towards the polymer-rich top phase $[87,88]$.

The partitioning of polyhydroxyalkanoate (PHA) from Cupriavidus necator $\mathrm{H}-16$ in the thermoseparating-based LBS showed a good setup in altering the $\mathrm{pH}$ system as compared with conventional PEG-based LBS [89]. PHA showed a purification factor and recovery yield of $3.67 \%$ and $63.5 \%$, respectively, at the $\mathrm{pH} 6$ which was better than the conventional PEG-based LBS that had zero recovery of PHA in the top phase when $\mathrm{pH}$ was less than 7 . However, there was a sudden drop in PHA recovery yield of $46.4 \%$ when the $\mathrm{pH}$ was adjusted to 8.0 to 8.8 in the system. Another study of extraction of BSA had shown that the different $\mathrm{pH}$ values could alter the net charge of targeted compound [90]. It was reported that the $\mathrm{pH}$ value increased from 6.0 to 9.0 which was larger than the isoelectric point of BSA ( $\mathrm{pI}=4.8$ ) resulted in a maximum recovery yield of $84.32 \%$. However, the high $\mathrm{pH}$ value is not favorable in the LBS since it can induce the protein denaturation.

Another experiment of antioxidants (i.e., xylooligosaccharides and phenol) extraction from wheat chaff explored the effect of $\mathrm{pH}$ on LBS [72]. The influence of $\mathrm{pH}$ value ranging from 2.5 to 7.0 was studied in the case of partitioning parameters of antioxidant such as recovery and partition coefficient. A maximum recovery of sugar ranging from $96 \%$ to $99 \%$ was obtained at $\mathrm{pH} 7.0$ but the recovery of phenol decreased which could be explained by the phenol compound having a low $\mathrm{pKa}$ value of 4.5. In extend, at $\mathrm{pH}$ values near $\mathrm{pKa}$ such as $\mathrm{pH} 4.0$ was reported that the partitioning of xylooligosaccharides was more towards the ethanol-rich top phase and phenol was more toward salt-rich bottom phase at the highest recovery of $75 \%$ and $77 \%$, respectively. Hence, it is important to examine the effect of $\mathrm{pH}$ at the optimum condition to enhance the purification factor and recovery yield of the target biomolecules as it could be damaged or denatured by varying the sensitivity of $\mathrm{pH}$ conditions.

\subsection{Temperature}

The effect of temperature is dependent on the type of phase-forming components used in the LBS and stability of target biomolecules from denaturation. A change in temperature also affects the viscosity and density of the interface in the LBS. In most cases, the optimum temperature within the range of 20 to $40{ }^{\circ} \mathrm{C}$ was utilized for maximum recovery and partitioning of target biomolecules. The effect of temperature on the extraction efficiency of CPC from Spirulina platensis microalgae was studied and the maximum extraction efficiency up to $99.0 \%$ was achieved near the temperature range of 308 $\mathrm{K}$ [46]. It was found that lowering the temperature to $298 \mathrm{~K}$ caused the rate of CPC recovery to decrease, resulting in a low extraction efficiency. The influence of temperature on extraction efficiency study of BSA and papain was evaluated [52]. However, the studies showed that the extraction efficiency of both BSA and papain decreased when the temperature was increased. This phenomenon was due to the increasing temperature which could inhibit the interaction of amino acid and surface water of protein, resulting in less efficiency of protein extraction [89]. Hence, the effect of temperature should be taken into consideration as the extraction efficiency of the biomolecule is dependent on the range of temperature in the LBS. 


\section{Future Prospect and Challenges of LBS Application}

The use of LBS is a promising separation technique for extraction of valuable biomolecules. The LBS can serve as an analytical tool to understand the chemical properties and behavior of target biomolecules. However, developing LBS as an alternative way for separation and purification for large-scale industrial application does encounter some key challenges that have to be re-addressed. One of the major concerns regarding the LBS is the partitioning coefficient $(\mathrm{K})$ of the biomolecules into the top phase which is mainly dependent on the key parameters. It is time-consuming and crucial to investigate each of the key parameters in order to determine the optimum condition for maximum purification and recovery of biomolecules. The selection of phase-forming components should also be made concerning to their biocompatibility, hazards and biodegradability. Therefore, this favors an alternative phase-forming component which is more environmentally friendly and highly biodegradable in the aquatic environment.

Another challenge that needs to be addressed in the LBS is the extraction of biomolecules from natural sources. Regardless of various studies reporting the efficiency of LBS in the extraction of biomolecules from natural sources and microbial fermentation broths, it is still difficult to understand the biomolecules partition behavior, particularly when a complex crude feedstock is added into the LBS. Moreover, the contaminants might have the similar characteristics with the target biomolecules in the crude feedstock. This will cause lower extraction efficiency during the interaction with the extraction medium in the LBS. The lack of understanding on the partition behavior remains a challenge in utilizing the LBS for the recovery of biomolecules.

Furthermore, there is still some unexplored technologies such as magnetic and microwave approach which can be integrated with LBS for enhancing biomolecules extraction efficiency. The implementation of these new advanced technologies would be beneficial to enhance the knowledge in LBS. Moreover, it has been proven that the present assisted technologies using bubble-, ultrasound-, and electricity-assisted technologies showed a promising prospect in the recovery and purification of biomolecules. However, these assisted technologies required an in-depth study due to the lack of knowledge between its physico-chemical mechanism aligned with the LBS.

To maximize the large-scale use of LBS requires an ideal optimization technique at where the system can perform at its best desired performance for various application. A recent review by Torres-Acosta et al., (2019) has comprehensively evaluated the strategies to incorporate the LBS technologies in the industry [91]. One of the most frequent optimization techniques used is univariate optimization or known as one-factor-at-a-time (OFAT) analysis is where a single parameter at the time after the other is selected based on its best performance. Aside from that, response surface methodology (RSM) is another optimization technique found in most literature studies. This optimization technique composed of a statistical design that allows a simultaneous variation of several parameters compared to OFAT which depends on a single parameter at a time. Lastly, genetic algorithms (GA) is less frequently used compared to RSM however can deliver excellent results. The fundamental of GA involves the natural genetic inheritance (genotype) which relate specifically to the raw information of LBS components such as concentration of alcohol, salt, $\mathrm{pH}$ system, and temperature and then interprets the results (i.e., recovery yield, partition coefficient, and separation efficient) based on the characteristic of the LBS. The advantages of this GA compared to RSM is that GA does not require a regression or model tool as the optimizing approach, as the LBS is based on the previous results. In general, these optimization strategies are one of the best-selling points to make LBS to be implemented at industrial scales.

Aside from that, another strategy which could beneficial to the LBS is to study the recyclability and reusability of the phase-forming components in LBS. This is to ensure that the LBS not only can be employed as a separation and purification technique, but also promoting a sustainable low-cost process in the downstream processes. On top of that, the implementation of extractive technologies such as fermentation, cell disruption, bioconversion, crystallization, distillation, and metallurgy can be proposed along with the LBS to allow the production and purification tasks to occur in one-step process. 
The advantages of this extractive technologies prevent the inhibition of the product and enhance the stability of biomolecules in the production stage. These benefits from extraction technologies should be further explored for the future development of LBS.

\section{Conclusions}

LBS is a simple, selective, scalable, and efficient tool to be utilized in downstream processing for the purification and recovery of biomolecules. However, it is still yet favorable to be used at the commercial scale as the complexity of the partitioning mechanism is difficult to predict. The challenges associated with the LBS techniques such as economic feasibility and the understanding of partition behavior need to be addressed to ensure the applicability in biotechnology industries. It is believed that more development along with various kind of technologies integrated in LBS will be discovered in the future. Hence, promoting the LBS to be used in commercial applications in recovering various high value bio-based products.

Author Contributions: Writing—original draft, K.S.K.; Writing-review \& editing, K.S.K., H.Y.L., K.W.C. and J.-W.L.; Conceptualization, P.L.S.; Supervision \& Funding acquisition, P.L.S., T.C.L. and H.-W.Y. All authors have read and agreed to the published version of the manuscript.

Funding: This work was supported by the Fundamental Research Grant Scheme, Malaysia [FRGS/1/ 2019/STG05/UNIM/02/2].

Conflicts of Interest: The authors declare that they have no conflicts of interests.

\section{References}

1. Khoo, K.S.; Lee, S.Y.; Ooi, C.W.; Fu, X.; Miao, X.; Ling, T.C.; Show, P.L. Recent Advances in Biorefinery of Astaxanthin from Haematococcus pluvialis. Bioresour. Technol. 2019, 288, 121606. [CrossRef] [PubMed]

2. Tham, P.E.; Ng, Y.J.; Sankaran, R.; Khoo, K.S.; Chew, K.W.; Yap, Y.J.; Malahubban, M.; Aziz Zakry, F.A.; Show, P.L. Recovery of Protein from Dairy Milk Waste Product Using Alcohol-Salt Liquid Biphasic Flotation. Processes 2019, 7, 875. [CrossRef]

3. Azevedo, A.M.; Rosa, P.A.; Ferreira, I.F.; Aires-Barros, M.R. Chromatography-free recovery of biopharmaceuticals through aqueous two-phase processing. Trends Biotechnol. 2009, 27, 240-247. [CrossRef] [PubMed]

4. Drexler, I.L.; Yeh, D.H. Membrane applications for microalgae cultivation and harvesting: A review. Rev. Environ. Sci. Bio 2014, 13, 487-504. [CrossRef]

5. Grossmann, L.; Ebert, S.; Hinrichs, J.; Weiss, J. Effect of precipitation, lyophilization, and organic solvent extraction on preparation of protein-rich powders from the microalgae Chlorella protothecoides. Algal. Res. 2018, 29, 266-276. [CrossRef]

6. Sankaran, R.; Manickam, S.; Yap, Y.J.; Ling, T.C.; Chang, J.-S.; Show, P.L. Extraction of proteins from microalgae using integrated method of sugaring-out assisted liquid biphasic flotation (LBF) and ultrasound. Ultrason. Sonochem. 2018, 48, 231-239. [CrossRef]

7. Khoo, K.S.; Chew, K.W.; Ooi, C.W.; Ong, H.C.; Ling, T.C.; Show, P.L. Extraction of natural astaxanthin from Haematococcus pluvialis using liquid biphasic flotation system. Bioresour. Technol. 2019, 290, 121794. [CrossRef]

8. Leong, H.Y.; Ooi, C.W.; Law, C.L.; Julkifle, A.L.; Ling, T.C.; Show, P.L. Application of liquid biphasic flotation for betacyanins extraction from peel and flesh of Hylocereus polyrhizus and antioxidant activity evaluation. Sep. Purif. Technol. 2018, 201, 156-166. [CrossRef]

9. Phong, W.N.; Le, C.F.; Show, P.L.; Chang, J.S.; Ling, T.C. Extractive disruption process integration using ultrasonication and an aqueous two-phase system for protein recovery from Chlorella sorokiniana. Eng. Life Sci. 2017, 17, 357-369. [CrossRef]

10. Phong, W.N.; Show, P.L.; Teh, W.H.; Teh, T.X.; Lim, H.M.Y.; binti Nazri, N.S.; Tan, C.H.; Chang, J.-S.; Ling, T.C. Proteins recovery from wet microalgae using liquid biphasic flotation (LBF). Bioresour. Technol. 2017, 244, 1329-1336. [CrossRef]

11. Lee, S.Y.; Khoiroh, I.; Ling, T.C.; Show, P.L. Aqueous Two-Phase Flotation for the Recovery of Biomolecules. Sep. Purif. Rev. 2016, 45, 81-92. [CrossRef] 
12. Sankaran, R.; Show, P.L.; Cheng, Y.-S.; Tao, Y.; Ao, X.; Nguyen, T.D.P.; Van Quyen, D. Integration Process for Protein Extraction from Microalgae Using Liquid Biphasic Electric Flotation (LBEF) System. Mol. Biotechnol. 2018, 60, 749-761. [CrossRef] [PubMed]

13. Koyande, A.K.; Chew, K.W.; Rambabu, K.; Tao, Y.; Chu, D.T.; Show, P.L. Microalgae: A potential alternative to health supplementation for humans. Food Science and Human Wellness. 2019, 8, 16-24. [CrossRef]

14. Chew, K.W.; Chia, S.R.; Krishnamoorthy, R.; Tao, Y.; Chu, D.-T.; Show, P.L. Liquid biphasic flotation for the purification of C-phycocyanin from Spirulina platensis microalga. Bioresour. Technol. 2019, 288, 121519. [CrossRef] [PubMed]

15. Van Berlo, M.; Luyben, K.C.A.; van der Wielen, L.A. Poly (ethylene glycol)-salt aqueous two-phase systems with easily recyclable volatile salts. J. Chromatogr. B Biomed. Sci. Appl. 1998, 711, 61-68. [CrossRef]

16. Grilo, A.L.; Raquel Aires-Barros, M.; Azevedo, A.M. Partitioning in aqueous two-phase systems: Fundamentals, applications and trends. Sep. Purif. Rev. 2016, 45, 68-80. [CrossRef]

17. Albertsson, P. Fractionation of particles and macromolecules in aqueous two-phase systems. Biochem. Pharmcol. 1961, 5, 351-358. [CrossRef]

18. Albertsson, P.A. Partitioning of Cell Particles and Macromolecules; Wiley: New York, NY, USA, 1986.

19. Asenjo, J.A.; Andrews, B.A. Aqueous two-phase systems for protein separation: Phase separation and applications. J. Chromatogr. A 2012, 1238, 1-10. [CrossRef]

20. Ooi, C.W.; Tey, B.T.; Hii, S.L.; Kamal, S.M.M.; Lan, J.C.W.; Ariff, A.; Ling, T.C. Purification of lipase derived from Burkholderia pseudomallei with alcohol/salt-based aqueous two-phase systems. Process Biochem. 2009, 44, 1083-1087. [CrossRef]

21. Zhao, L.; Peng, Y.-L.; Gao, J.-M.; Cai, W.-M. Bioprocess intensification: An aqueous two-phase process for the purification of C-phycocyanin from dry Spirulina platensis. Eur. Food Res. Technol. 2014, 238, 451-457. [CrossRef]

22. Rosa, P.A.J.; Ferreira, I.F.; Azevedo, A.M.; Aires-Barros, M.R. Aqueous two-phase systems: A viable platform in the manufacturing of biopharmaceuticals. J. Chromatogr. A 2010, 1217. [CrossRef] [PubMed]

23. Raja, S.; Murty, V.R.; Thivaharan, V.; Rajasekar, V.; Ramesh, V. Aqueous two phase systems for the recovery of biomolecules-a review. Sci. Technol. 2011,1,7-16. [CrossRef]

24. Iqbal, M.; Tao, Y.; Xie, S.; Zhu, Y.; Chen, D.; Wang, X.; Huang, L.; Peng, D.; Sattar, A.; Shabbir, M.A.B. Aqueous two-phase system (ATPS): An overview and advances in its applications. Biol. Proced. Online 2016, 18, 18. [CrossRef] [PubMed]

25. Hatti-Kaul, R. Aqueous Two-Phase Systems: Methods and Protocols; Springer Science \& Business Media: Berlin/Heidelberg, Germany, 2000; Volume 11.

26. Raja, S.; Murty, V.R. Development and evaluation of environmentally benign aqueous two phase systems for the recovery of proteins from tannery waste water. ISRN Chem. Eng. 2012. [CrossRef]

27. Johansson, H.-O.; Feitosa, E.; Junior, A.P. Phase diagrams of the aqueous two-phase systems of poly (ethylene glycol)/sodium polyacrylate/salts. Polymers 2011, 3, 587-601. [CrossRef]

28. Hou, D.; Li, Y.; Cao, X. Synthesis of two thermo-sensitive copolymers forming aqueous two-phase systems. Sep. Purif. Technol. 2014, 122, 217-224. [CrossRef]

29. Tan, Z.; Li, F.; Zhao, C.; Teng, Y.; Liu, Y. Chiral separation of mandelic acid enantiomers using an aqueous two-phase system based on a thermo-sensitive polymer and dextran. Sep. Purif. Technol. 2017, 172, 382-387. [CrossRef]

30. Leong, Y.K.; Lan, J.C.W.; Loh, H.S.; Ling, T.C.; Ooi, C.W.; Show, P.L. Thermoseparating aqueous two-phase systems: Recent trends and mechanisms. J. Sep. Sci. 2016, 39, 640-647. [CrossRef]

31. Show, P.L.; Tan, C.P.; Shamsul Anuar, M.; Ariff, A.; Yusof, Y.A.; Chen, S.K.; Ling, T.C. Extractive fermentation for improved production and recovery of lipase derived from Burkholderia cepacia using a thermoseparating polymer in aqueous two-phase systems. Bioresour. Technol. 2012, 116. [CrossRef]

32. Ng, H.S.; Tan, C.P.; Mokhtar, M.N.; Ibrahim, S.; Ariff, A.; Ooi, C.W.; Ling, T.C. Recovery of Bacillus cereus cyclodextrin glycosyltransferase and recycling of phase components in an aqueous two-phase system using thermo-separating polymer. Sep. Purif. Technol. 2012, 89, 9-15. [CrossRef]

33. Lin, Y.K.; Show, P.L.; Yap, Y.J.; Tan, C.P.; Ng, E.-P.; Ariff, A.B.; Annuar, M.S.B.M.; Ling, T.C. Direct recovery of cyclodextringlycosyltransferase from Bacillus cereus using aqueous two-phase flotation. J. Biosci. Bioeng. 2015, 120, 684-689. [CrossRef] [PubMed] 
34. Jong, W.Y.L.; Show, P.L.; Ling, T.C.; Tan, Y.S. Recovery of lignin peroxidase from submerged liquid fermentation of Amauroderma rugosum (Blume \& T. Nees) Torrend using polyethylene glycol/salt aqueous two-phase system. J. Biosci. Bioeng. 2017, 124, 91-98. [PubMed]

35. Lin, Y.K.; Ooi, C.W.; Tan, J.S.; Show, P.L.; Ariff, A.; Ling, T.C. Recovery of human interferon alpha-2b from recombinant Escherichia coli using alcohol/salt-based aqueous two-phase systems. Sep. Purif. Technol. 2013, 120, 362-366. [CrossRef]

36. Chia, S.R.; Show, P.L.; Phang, S.-M.; Ling, T.C.; Ong, H.C. Sustainable approach in phlorotannin recovery from macroalgae. J. Biosci. Bioeng. 2018, 126, 220-225. [CrossRef]

37. Smiglak, M.; Metlen, A.; Rogers, R.D. The Second Evolution of Ionic Liquids: From Solvents and Separations to Advanced Materials Energetic Examples from the Ionic Liquid Cookbook. Acc. Chem. Res. 2007, 40, 1182-1192. [CrossRef]

38. Lee, S.Y.; Vicente, F.A.; e Silva, F.A.; Sintra, T.E.; Taha, M.; Khoiroh, I.; Coutinho, J.O.A.; Show, P.L.; Ventura, S.P. Evaluating self-buffering ionic liquids for biotechnological applications. ACS Sustain. Chem. Eng. 2015, 3, 3420-3428. [CrossRef]

39. Zhang, S.; Sun, N.; He, X.; Lu, X.; Zhang, X. Physical properties of ionic liquids: Database and evaluation. J. Phys. Chem. Ref. Data 2006, 35, 1475-1517. [CrossRef]

40. Lee, S.Y.; Khoiroh, I.; Ooi, C.W.; Ling, T.C.; Show, P.L. Recent advances in protein extraction using ionic liquid-based aqueous two-phase systems. Sep. Purif. Rev. 2017, 46, 291-304. [CrossRef]

41. Ostadjoo, S.; Berton, P.; Shamshina, J.L.; Rogers, R.D. Scaling-up ionic liquid-based technologies: How much do we care about their toxicity? Prima facie information on 1-ethyl-3-methylimidazolium acetate. Toxicol. Sci. 2017, 161, 249-265. [CrossRef]

42. Sun, N.; Rahman, M.; Qin, Y.; Maxim, M.L.; Rodríguez, H.; Rogers, R.D. Complete dissolution and partial delignification of wood in the ionic liquid 1-ethyl-3-methylimidazolium acetate. Green Chem. 2009, 11, 646-655. [CrossRef]

43. Swatloski, R.P.; Spear, S.K.; Holbrey, J.D.; Rogers, R.D. Dissolution of cellose with ionic liquids. J. Am. Chem. Soc. 2002, 124, 4974-4975. [CrossRef] [PubMed]

44. Gutowski, K.E.; Broker, G.A.; Willauer, H.D.; Huddleston, J.G.; Swatloski, R.P.; Holbrey, J.D.; Rogers, R.D. Controlling the aqueous miscibility of ionic liquids: Aqueous biphasic systems of water-miscible ionic liquids and water-structuring salts for recycle, metathesis, and separations. J. Am. Chem. Soc. 2003, 125, 6632-6633. [CrossRef] [PubMed]

45. Du, Z.; Yu, Y.L.; Wang, J.H. Extraction of proteins from biological fluids by use of an ionic liquid/aqueous two-phase system. Chem. A Eur. J. 2007, 13, 2130-2137. [CrossRef] [PubMed]

46. Ng, H.S.; Ooi, C.W.; Show, P.L.; Tan, C.P.; Ariff, A.; Moktar, M.N.; Ng, E.-P.; Ling, T.C. Recovery of Bacillus cereus cyclodextrin glycosyltransferase using ionic liquid-based aqueous two-phase system. Sep. Purif. Technol. 2014, 138, 28-33. [CrossRef]

47. Chang, Y.-K.; Show, P.-L.; Lan, J.C.-W.; Tsai, J.-C.; Huang, C.-R. Isolation of C-phycocyanin from Spirulina platensis microalga using Ionic liquid based aqueous two-phase system. Bioresour. Technol. 2018, 270, 320-327. [CrossRef]

48. Garcia, E.S.; Ruiz, C.A.S.; Tilaye, T.; Eppink, M.H.; Wijffels, R.H.; van den Berg, C. Fractionation of proteins and carbohydrates from crude microalgae extracts using an ionic liquid based-aqueous two phase system. Sep. Purif. Technol. 2018, 204, 56-65. [CrossRef]

49. Abbott, A.P.; Boothby, D.; Capper, G.; Davies, D.L.; Rasheed, R.K. Deep eutectic solvents formed between choline chloride and carboxylic acids: Versatile alternatives to ionic liquids. J. Am. Chem. Soc. 2004, 126, 9142-9147. [CrossRef]

50. Shishov, A.; Bulatov, A.; Locatelli, M.; Carradori, S.; Andruch, V. Application of deep eutectic solvents in analytical chemistry. A review. Microchem. J. 2017, 135, 33-38. [CrossRef]

51. Paiva, A.; Craveiro, R.; Aroso, I.; Martins, M.; Reis, R.L.; Duarte, A.R.C. Natural deep eutectic solvents-solvents for the 21st century. ACS Sustain. Chem. Eng. 2014, 2, 1063-1071. [CrossRef]

52. Dai, Y.; van Spronsen, J.; Witkamp, G.-J.; Verpoorte, R.; Choi, Y.H. Natural deep eutectic solvents as new potential media for green technology. Anal. Chim. Acta 2013, 766, 61-68. [CrossRef]

53. Pang, J.; Sha, X.; Chao, Y.; Chen, G.; Han, C.; Zhu, W.; Li, H.; Zhang, Q. Green aqueous biphasic systems containing deep eutectic solvents and sodium salts for the extraction of protein. RSC Adv. 2017, 7, 49361-49367. [CrossRef] 
54. Zeng, Q.; Wang, Y.; Huang, Y.; Ding, X.; Chen, J.; Xu, K. Deep eutectic solvents as novel extraction media for protein partitioning. Analyst 2014, 139, 2565-2573. [CrossRef]

55. Zhang, X.; Teng, G.; Zhang, J. Deep eutectic solvents aqueous two-phase system based ultrasonically assisted extraction of ursolic acid (UA) from Cynomorium songaricum Rupr. Chem. Eng. Commun. 2019, 206, 419-431. [CrossRef]

56. Weschayanwiwat, P.; Kunanupap, O.; Scamehorn, J.F. Benzene removal from waste water using aqueous surfactant two-phase extraction with cationic and anionic surfactant mixtures. Chemosphere 2008, 72, 1043-1048. [CrossRef] [PubMed]

57. Selber, K.; Tjerneld, F.; Collén, A.; Hyytiä, T.; Nakari-Setälä, T.; Bailey, M.; Fagerström, R.; Kan, J.; Van Der Laan, J.; Penttilä, M. Large-scale separation and production of engineered proteins, designed for facilitated recovery in detergent-based aqueous two-phase extraction systems. Process Biochem. 2004, 39, 889-896. [CrossRef]

58. Amid, M.; Manap, M.; Hussin, M.; Mustafa, S. A novel aqueous two phase system composed of surfactant and xylitol for the purification of lipase from pumpkin (Cucurbita moschata) seeds and recycling of phase components. Molecules 2015, 20, 11184-11201. [CrossRef] [PubMed]

59. Sankaran, R.; Show, P.L.; Yap, Y.J.; Tao, Y.; Ling, T.C.; Tomohisa, K. Green technology of liquid biphasic flotation for enzyme recovery utilizing recycling surfactant and sorbitol. Clean Technol. Environ. Policy 2018, 20, 2001-2012. [CrossRef]

60. Sebba, F. Ion Flotation; Elsevier: Amsterdam, The Netherlands, 1962; Volume 30.

61. Sankaran, R.; Show, P.L.; Lee, S.Y.; Yap, Y.J.; Ling, T.C. Integration process of fermentation and liquid biphasic flotation for lipase separation from Burkholderia cepacia. Bioresour. Technol. 2018, 250, 306-316. [CrossRef]

62. Mathiazakan, P.; Shing, S.Y.; Ying, S.S.; Kek, H.K.; Tang, M.S.; Show, P.L.; Ooi, C.-W.; Ling, T.C. Pilot-scale aqueous two-phase floatation for direct recovery of lipase derived from Burkholderia cepacia strain ST8. Sep. Purif. Technol. 2016, 171, 206-213. [CrossRef]

63. Bi, P.-y.; Dong, H.-r.; Yuan, Y.-c. Application of aqueous two-phase flotation in the separation and concentration of puerarin from Puerariae extract. Sep. Purif. Technol. 2010, 75, 402-406. [CrossRef]

64. Jiang, B.; Wang, L.; Na, J.; Zhang, X.; Yuan, Y.; Liu, C.; Feng, Z. Environmentally-friendly strategy for separation of $\alpha$-lactalbumin from whey by aqueous two phase flotation. Arab. J. Chem. 2018, 13, 3391-3402. [CrossRef]

65. Wu, X.; Joyce, E.M.; Mason, T.J. The effects of ultrasound on cyanobacteria. Harmful Algae 2011, 10, 738-743. [CrossRef]

66. Wang, M.; Yuan, W.; Jiang, X.; Jing, Y.; Wang, Z. Disruption of microalgal cells using high-frequency focused ultrasound. Bioresour. Technol. 2014, 153, 315-321. [CrossRef]

67. Gerde, J.A.; Montalbo-Lomboy, M.; Yao, L.; Grewell, D.; Wang, T. Evaluation of microalgae cell disruption by ultrasonic treatment. Bioresour. Technol. 2012, 125, 175-181. [CrossRef] [PubMed]

68. Chemat, F.; Rombaut, N.; Sicaire, A.; Meullemiestre, A.; Abert-vian, M.; Fabiano-Tixier, A.; Abert-vian, M. Ultrasonics Sonochemistry Ultrasound assisted extraction of food and natural products. Mechanisms, techniques, combinations, protocols and applications. A review. Ultrason. Sonochem. 2017, 34, 540-560.

69. Pakhale, S.V.; Vetal, M.D.; Rathod, V.K. Separation of bromelain by aqueous two phase flotation. Sep. Sci. Technol. 2013, 48, 984-989. [CrossRef]

70. Rahim, A.H.A.; Khoo, K.S.; Yunus, N.M.; Hamzah, W.S.W. Ether-Functionalized Ionic Liquids as Solvent for Gigantochloa Scortechini Dissolution. Proceedings of AIP Conference Proceedings, Cesme-Izmir, Turkey, 26-30 May 2019; p. 020025.

71. Dong, B.; Yuan, X.; Zhao, Q.; Feng, Q.; Liu, B.; Guo, Y.; Zhao, B. Ultrasound-assisted aqueous two-phase extraction of phenylethanoid glycosides from Cistanche deserticola YC Ma stems. J. Sep. Sci. 2015, 38, 1194-1203. [CrossRef] [PubMed]

72. Đorđević, T.; Antov, M. Ultrasound assisted extraction in aqueous two-phase system for the integrated extraction and separation of antioxidants from wheat chaff. Sep. Purif. Technol. 2017, 182, 52-58. [CrossRef]

73. Eing, C.J.; Bonnet, S.; Pacher, M.; Puchta, H.; Frey, W. Effects of nanosecond pulsed electric field exposure on Arabidopsis thaliana. IEEE Trans. Dielectr. Electr. Insul. 2009, 16, 1322-1328. [CrossRef]

74. Kotnik, T.; Frey, W.; Sack, M.; Meglič, S.H.; Peterka, M.; Miklavčič, D. Electroporation-based applications in biotechnology. Trends Biotechnol. 2015, 33, 480-488. [CrossRef] 
75. Luengo, E.; Condón-Abanto, S.; Álvarez, I.; Raso, J. Effect of pulsed electric field treatments on permeabilization and extraction of pigments from Chlorella vulgaris. J. Membr. Biol. 2014, 247, 1269-1277. [CrossRef]

76. Leong, H.Y.; Ooi, C.W.; Law, C.L.; Julkifle, A.L.; Katsuda, T.; Show, P.L. Integration process for betacyanins extraction from peel and flesh of Hylocereus polyrhizus using liquid biphasic electric flotation system and antioxidant activity evaluation. Sep. Purif. Technol. 2019, 209, 193-201. [CrossRef]

77. 't Lam, G.P.; van der Kolk, J.A.; Chordia, A.; Vermuë, M.H.; Olivieri, G.; Eppink, M.H.; Wijffels, R.H. Mild and selective protein release of cell wall deficient microalgae with pulsed electric field. ACS Sustain. Chem. Eng. 2017, 5, 6046-6053. [CrossRef]

78. Phong, W.N.; Show, P.L.; Chow, Y.H.; Ling, T.C. Recovery of biotechnological products using aqueous two phase systems. J. Biosci. Bioeng. 2018, 126, 273-281. [CrossRef] [PubMed]

79. Santos, S.B.; Reis, I.A.; Silva, C.P.; Campos, A.F.; Ventura, S.P.; Soares, C.M.; Lima, Á.S. Selective partition of caffeine from coffee bean and guaraná seed extracts using alcohol-salt aqueous two-phase systems. Sep. Sci. Technol. 2016, 51, 2008-2019. [CrossRef]

80. Huang, L.; Li, W.; Feng, Y.; Fang, X.; Li, J.; Gao, Z.; Li, H. Simultaneous recovery of glycyrrhizic acid and liquiritin from Chinese licorice root (Glycyrrhiza uralensis Fisch) by aqueous two-phase system and evaluation biological activities of extracts. Sep. Sci. Technol. 2018, 53, 1342-1350. [CrossRef]

81. Wang, Y.; Liu, Y.; Han, J.; Hu, S. Application of water-miscible alcohol-based aqueous two-phase systems for extraction of dyes. Sep. Sci. Technol. 2011, 46, 1283-1288. [CrossRef]

82. Wingfield, P. Protein precipitation using ammonium sulfate. Curr. Protoc. Protein Sci. 1998, 13, A. 3F. 1-A. 3F. 8.

83. Lu, Y.; Yu, M.; Tan, Z.; Yan, Y. Phase equilibria and salt effect on the aqueous two-phase system of polyoxyethylene cetyl ether and sulfate salt at three temperatures. J. Chem. Eng. Data 2016, 61, 2135-2143. [CrossRef]

84. Yang, L.; Huo, D.; Hou, C.; He, K.; Lv, F.; Fa, H.; Luo, X. Purification of plant-esterase in PEG1000/NaH2PO4 aqueous two-phase system by a two-step extraction. Process Biochem. 2010, 45, 1664-1671. [CrossRef]

85. Goja, A.M.; Yang, H.; Cui, M.; Li, C. Aqueous two-phase extraction advances for bioseparation. J. Bioprocess. Biotechnol. 2013, 4, 1-8.

86. Karr, L.J.; Shafer, S.G.; Harris, J.M.; Van Alstine, J.M.; Snyder, R.S. Immuno-affinity partition of cells in aqueous polymer two-phase systems. J. Chromatogr. A 1986, 354, 269-282. [CrossRef]

87. Andrews, B.; Schmidt, A.; Asenjo, J. Correlation for the partition behavior of proteins in aqueous two-phase systems: Effect of surface hydrophobicity and charge. Biotechnol. Bioeng. 2005, 90, 380-390. [CrossRef] [PubMed]

88. Olivera-Nappa, A.; Lagomarsino, G.; Andrews, B.A.; Asenjo, J.A. Effect of electrostatic energy on partitioning of proteins in aqueous two-phase systems. J. Chromatogr. B 2004, 807, 81-86. [CrossRef] [PubMed]

89. Chakraborty, A.; Sen, K. Impact of $\mathrm{pH}$ and temperature on phase diagrams of different aqueous biphasic systems. J. Chromatogr. A 2016, 1433, 41-55. [CrossRef] [PubMed]

90. Chow, Y.H.; Yap, Y.J.; Tan, C.P.; Anuar, M.S.; Tejo, B.A.; Show, P.L.; Ariff, A.B.; Ng, E.-P.; Ling, T.C. Characterization of bovine serum albumin partitioning behaviors in polymer-salt aqueous two-phase systems. J. Biosci. Bioeng. 2015, 120, 85-90. [CrossRef] [PubMed]

91. Torres-Acosta, M.A.; Mayolo-Deloisa, K.; González-Valdez, J.; Rito-Palomares, M. Aqueous Two-Phase Systems at Large Scale: Challenges and Opportunities. Biotechnol. J. 2019, 14, 1800117. [CrossRef] [PubMed]

(C) 2020 by the authors. Licensee MDPI, Basel, Switzerland. This article is an open access article distributed under the terms and conditions of the Creative Commons Attribution (CC BY) license (http://creativecommons.org/licenses/by/4.0/). 